\title{
My-Wakaf: A Waqf of Property Management Application
}

\author{
Razin Azri Mohamad Razid ${ }^{1}$, Alif Faisal Ibrahim²*, Muhammad Nabil Fikri Jamaluddin ${ }^{3}$, Ray Adderley JM \\ Gining ${ }^{4}$ \\ 1,2,3,4 Faculty of Computer and Mathematical Sciences, \\ Universiti Teknologi MARA, Perlis Branch, Arau Campus, 02600 Arau, Perlis
}

Corresponding author: *aliffaisal@uitm.edu.my

Received Date: 1 July 2021

Accepted Date: 12 August 2021

Published Date: 1 September 2021

\section{HIGHLIGHTS}

- Current waqf property or assets management is limited to manual method of documentation.

- Therefore, an Android application was developed using support from Firebase real-time database to store all necessary details of waqf management.

- Users or waqif can submit application for their assets to be approved as waqf property and will be verified by staffs or nazir as representative from state religious council.

- User acceptance testing results shows overall positive feedback on the use of My-Wakaf app to help state religious councils to move away from traditional method of managing waqf property.

\begin{abstract}
In almost every Islamic country, the number of waqf properties is increasing at an exponential rate. As a result, managing such abundant amount of waqf properties can be very tedious and challenging. In Malaysia, waqf properties is managed by respective State Islamic Religious Council and are still using traditional method of recording all waqf asset. As a result, the My-Wakaf prototype mobile application was created to aid with the workload of managing waqf assets or properties. The methodology used for the project is the Waterfall model that is based on the original System Development Life Cycle (SDLC) that have 5 phases which are Planning, Design, Development, Testing and Documentation phase. My-Wakaf application is developed using Android Studio and it is integrated with Firebase Cloud database to help store waqf assets information securely to be accessed anywhere, reducing the human errors and cost of managing such properties. According to a user acceptability test conducted on numerous responders, the majority of them were highly happy with the My-Wakaf application's general functionality. Finally, it is intended that My-Wakaf would help the Muslim community as a whole by increasing awareness of waqf knowledge and stimulating economic growth.
\end{abstract}

Keywords: waqf management, waqf of property, mobile application, Islamic wealth 


\section{INTRODUCTION}

The word waqf originates from the Arabic language and means "to stop," which alludes to the concepts of waqf, in which a Muslim individual gives waqf to cease his or her control of a particular asset, and the asset then belongs to Allah (Abd Jalil, 2020). Waqf as part of endowment is one of key component in providing economic growth for Muslim community (Mat Rani \& Abdul Aziz, 2010).

Waqf has three basic components, one of which is the "waqif," or the individual who contributes the asset or property for waqf. The "mauquf," which refers to the waqif's asset, and the "mauquf alaih," which refers to the waqf's recipient (Abd Jalil, 2020).In addition, there are three types of waqf, which are property, corporate and cash. This research focuses more on property waqf or non-perishable property such as plots of land, real estate etc (Hassan \& Shahid, 2010). Despite the fact that the number of waqf properties is growing at an exponential rate in practically all Islamic nations, calls for more efficient management and better value for waqf holdings are becoming increasingly urgent (Hassan \& Shahid, 2010). In truth, waqf management in Malaysia was plagued by inefficiencies in the manner waqf properties were managed, with the bulk of waqf properties being underutilised (Mohd Noor et al., 2014).

In a paper written by Abas \& Raji (2018), among few factors contributing to inefficient management and maintenance of waqf properties is the lack of data or information updates from time to time. Furthermore, it has been found that one of the challenges faced by several state religious councils is the poor documentation management of waqf assets. This is simply due to the fact that the essential data must still be stored manually using a traditional system (Hasan et al., 2015). Therefore, the record of waqf land needs to be updated with complete and orderly information, as well as to provide a systematic online database to be easily reached by the waqf management and waqif as well. This is to enable them to review the records, update information, and check the status of endowment for each land, broadcasting of the proclamation and the recommendation of the audit.

Nowadays, most businesses utilise mobile applications as an alternative to websites or online portals. Therefore, managing waqf properties using mobile application, people can easily access and participate in waqf to perform worship to Allah. In addition, the mobile application can help respective State Islamic Religious Council (SIRC) to better manage waqf properties.

\section{LITERATURE REVIEW}

\section{Related Works}

This section discusses few examples of previous studies on waqf management systems.

Wakifu: Digital Based Wakaf in Campus Environment as Education and Administration Since Early 
A study by (Mukti, 2021) focuses on an innovation of waqf management systems that can be applied in a student environment. The system was developed to increase awareness and educate students on waqf literacy. The system is named Wakifu which is derived from the word Wakif who donates his or her wealth. As part of the future Muslim community, it is imperative that these students can actively involved in the act of managing waqf as a waqif (who gives donation) and also a nazhir, which are selected students who will be directly responsible on the management of waqf assets or properties. Figure 1 show the illustration of the Wakifu innovation.

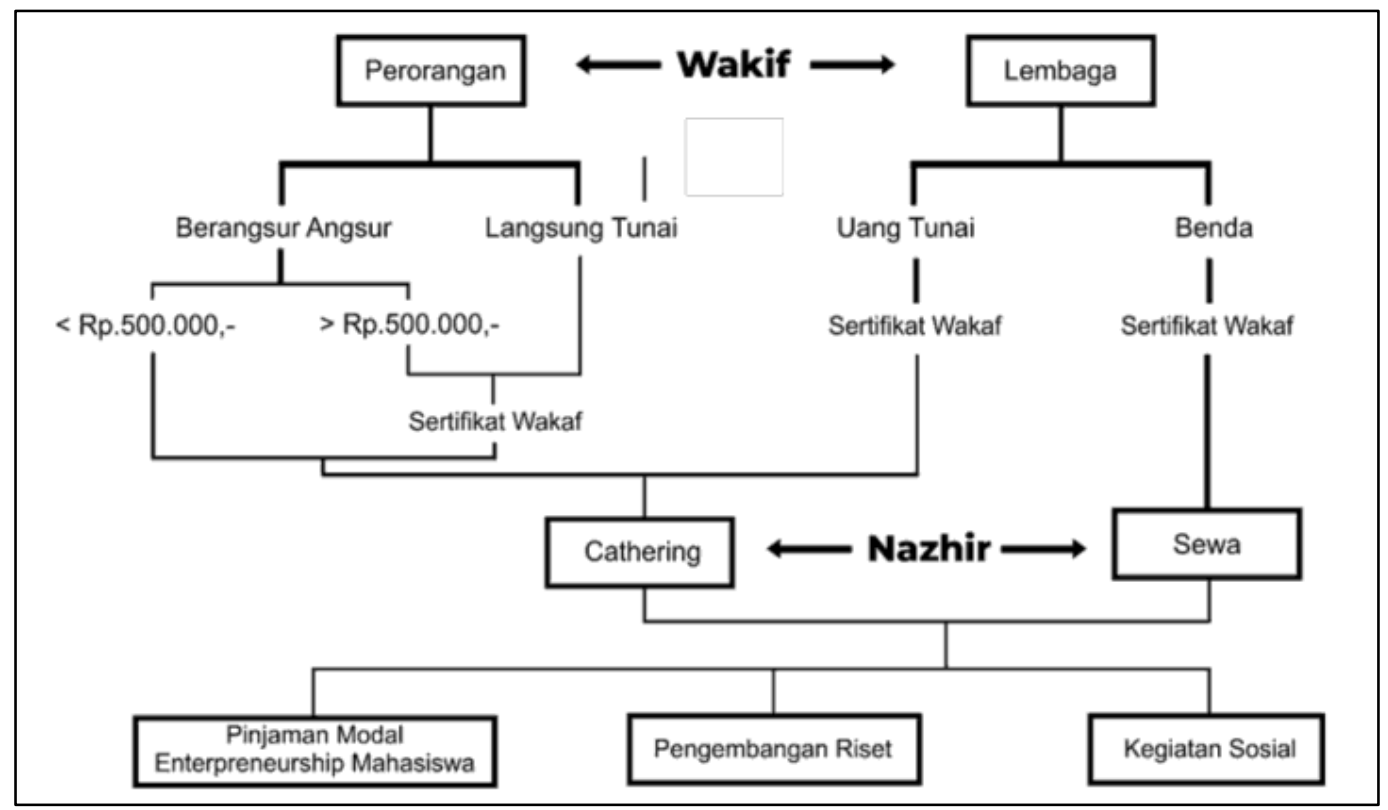

Figure 1: Wakifu Innovation (Source: Mukti, 2021)

\section{The Waqf Cemetery Information System}

Komalasari (2020) outlined a Waqf Cemetery Information System that was created to manage data from waqf/individual/private cemetery site in Bandung, Indonesia. The system was built mainly for real-time recording and reporting of the Waqf/individual/private cemetery data. This system is a web application that can be accessed by a browser and is connected to a local network or the Internet. Figure 2 shows an example of form interface for adding waqf land information. Benefits of using this system includes faster data reporting of the cemetery land, as well as reducing human errors and improving services to the local community. 


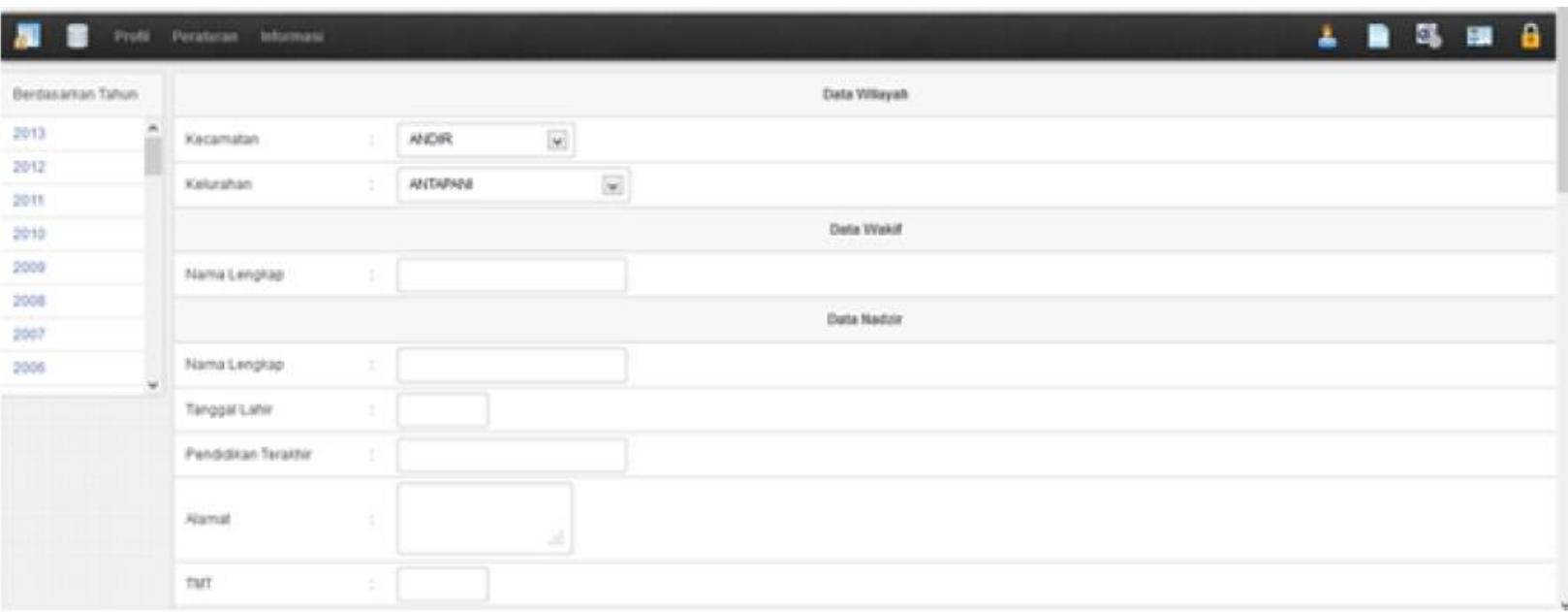

Figure 2: Add Data Waqf Land Form (Source: Komalasari, 2020)

\section{METHODOLOGY}

Figure 3 below shows the overview of methodology used in this research. There are a total of five phases including planning, design, development, testing, and documentation phase.

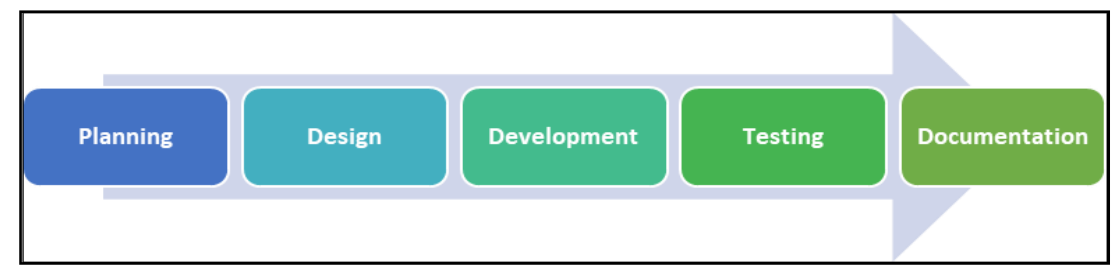

Figure 3: Methodology

The initiation part of the project begins with the planning phase. The area of the project has been discovered which is about the waqf of property management. The necessary prerequisites for building this application are derived from a literature review of different journal articles, conferences, and academic resources. Next is the design phase which involved designing the flow of the system as well as the user interface concept.

Once all design requirements are made, the development phase begins. The development phase is split into two parts: the mobile application and the online application that will be accessed by the administrator, staff, and nazir. As part of the functionality testing, a thorough coding procedure is carried out to guarantee that all modules are functioning properly.

The testing phase is a mandatory phase to make sure the system of the application runs smoothly without errors and reach the user's satisfaction. Testing which was carried out with the real user of the system which are the target users. The motive of the user acceptance testing is to get the feedback from real users so the researcher can improve and debug the system if needed. Finally, during the methodology's Documentation phase, all significant outcomes and discussions are meticulously documented in the form of a report.

\section{System Architecture}


Figure 4 shows the system architecture for My-Wakaf application. There are two types of users: waqif (user) and nazir (admin). Users can install the Android application on their smartphone and register their details before submitting their asset or property information for waqf. After their information has been updated in the database, the administrator or nazir will be able to access all submission via a Web-based system and verify according to their respective standard operating procedures. All information is safely secured in Firebase cloud storage.

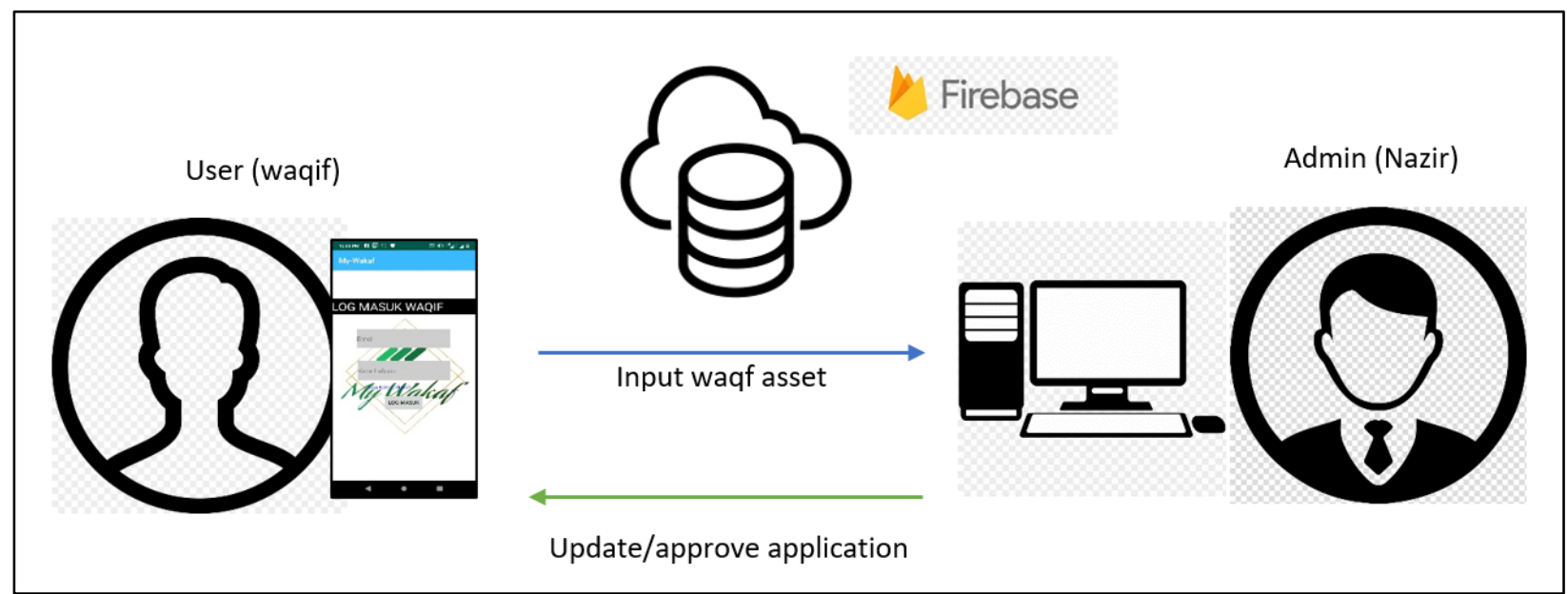

Figure 4: System architecture of My-Wakaf application

\section{Use Case diagram}

Based on Figure 5, users are able to register, login, view info about waqf, submit Mawquf application form, check status of application and make appointment if there are issues related to their application. For the staff as an administrator, they can validate the asset or property, schedule an appointment and manage registered users. 


\section{DEVELOPMENT}

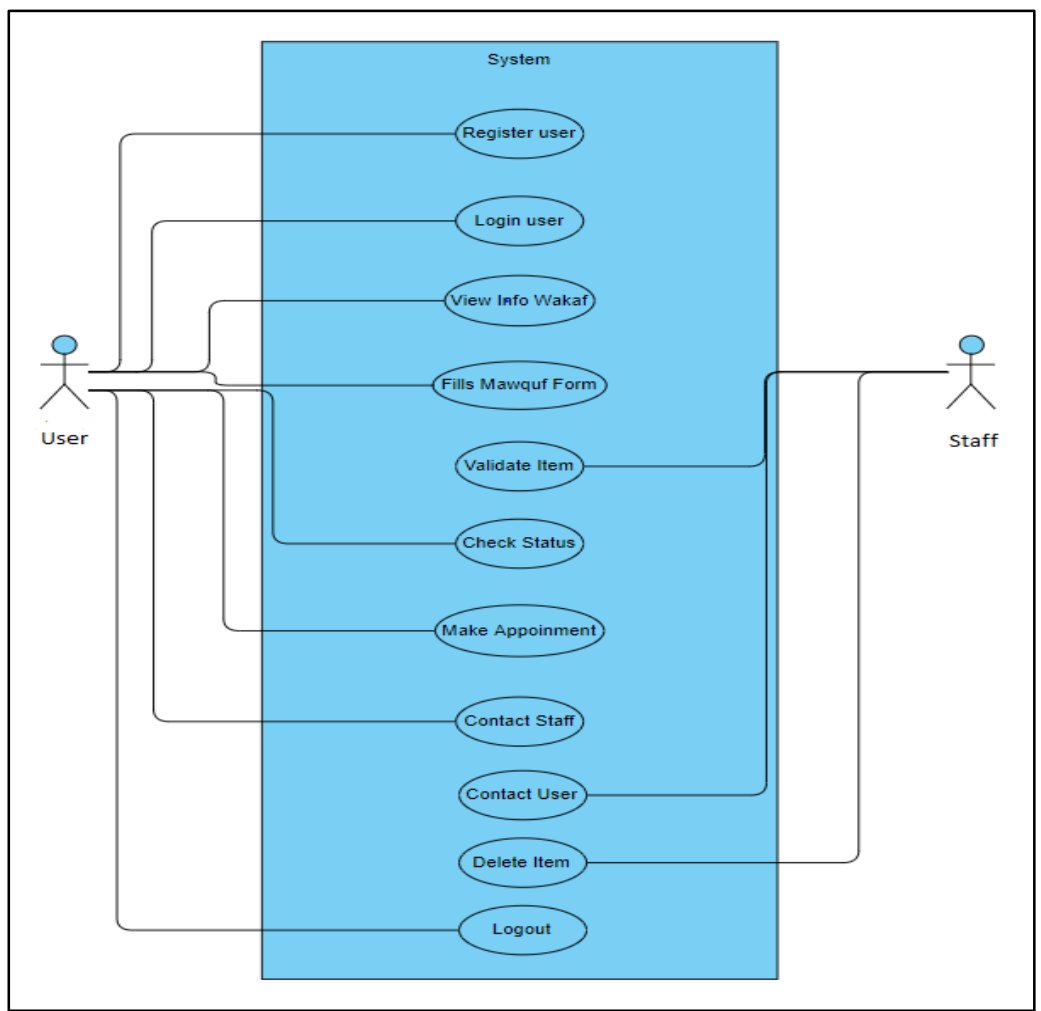

Figure 5: Use Case Diagram for My-Wakaf application

This section briefly explained some key important aspects of development of My-Wakaf application. There are two main components of this application, where using a real time database is important to ensure the app is reliable to be use in waqf management process.

\section{Firebase Cloud Database Setup}

To initialize the Firestore, a method must be called to enable the use of Firestore function within the application. The initialization needs to be made in every available page in the application. Figure 6 below shows how the methods are called in every page of the application. Cloud Firestore stores data that is contained in collections of files. The first time adding an information to the file, the Cloud Firestore generates collections and files implicitly. Figure 7 described the method needs to be called in order to create and call the collections of document in Firestore. 


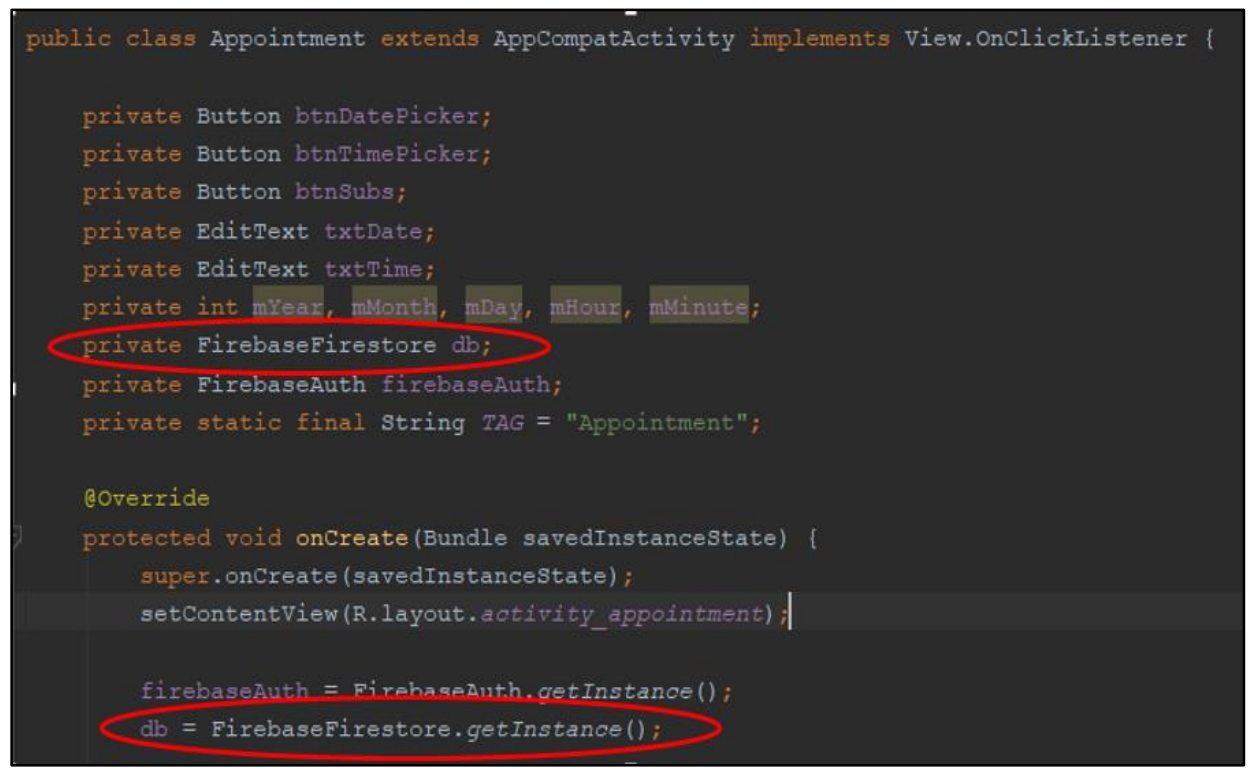

Figure 6: Firestore Declaration

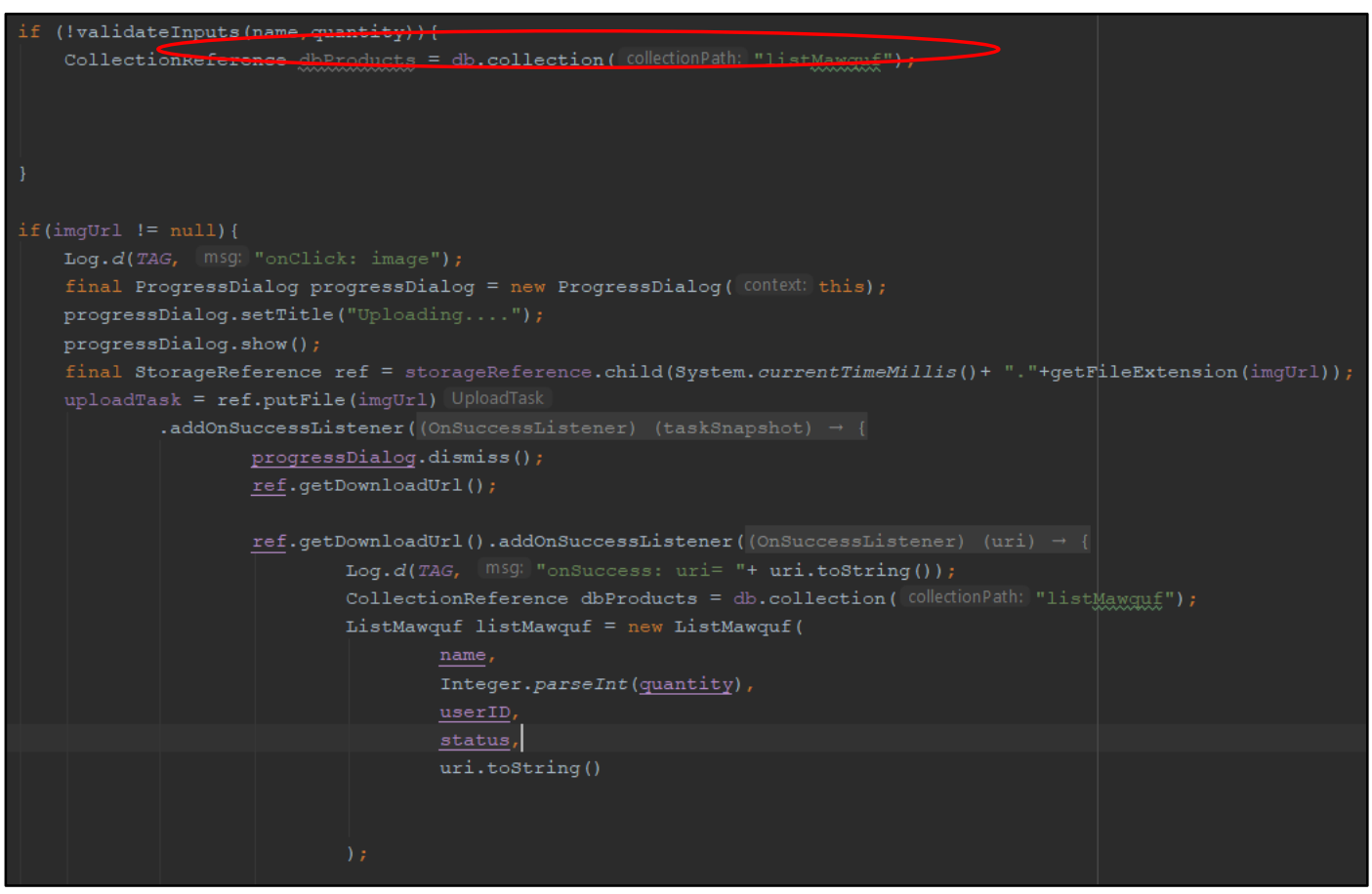

Figure 7: Firestore Reference

Cloud Firestore offers powerful query features to determine which documents from a collection or collection category to retrieve. As defined in get Data and Get Realtime Updates, these queries can also be used with either get() or addSnaptshopListener(). For this application, an adapter is used to code the queries since fragment view and list view is used for the purpose of viewing the data.

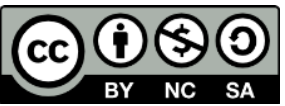




\section{Firebase Cloud Database Setup for Web-based System}

For the administration side, a web application is developed to help nazir or person in charge (PIC) from State Islamic Religious Council to monitor and manage all waqf properties and assets that have been registered by the mobile app users. The implementation for the web application is a bit different due to use of JavaScript. To make the service functional, the Firebase implementation needs to be called in every page of the web development at the very bottom of the page. The developer also includes the configuration of the Firebase below the script of the implementation. The configuration is important to identify which Firebase is currently connected. Figure 8 shows the implementation and configuration for the Firebase Cloud Database.

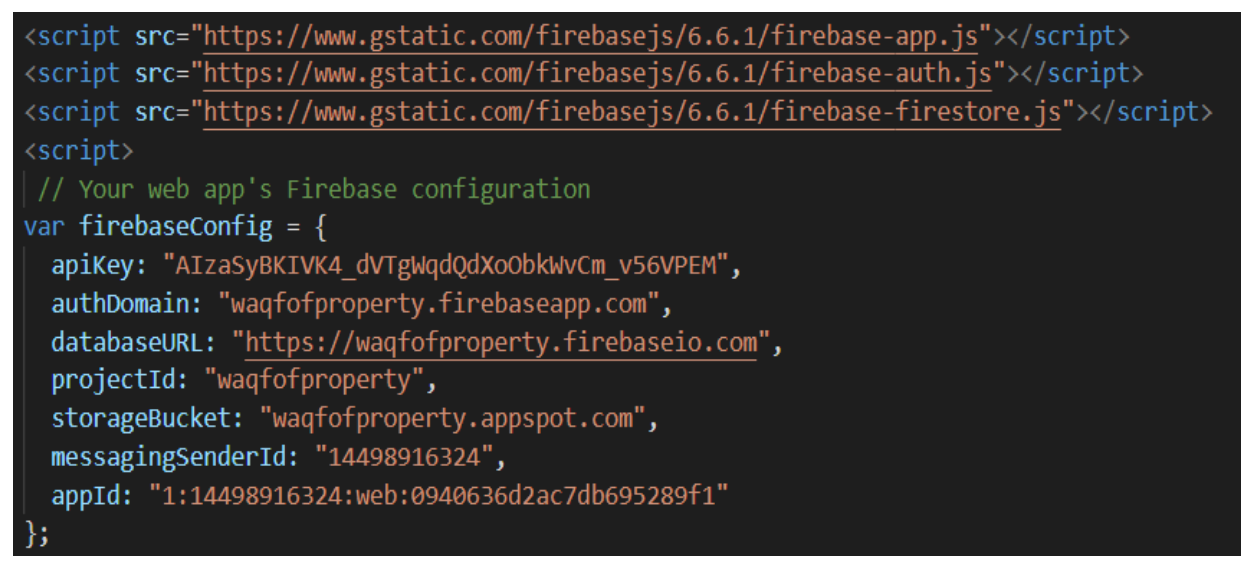

Figure 8: Firebase Implementation In Web

\section{User Interface of My-Wakaf Application}

After the app has been installed, users are welcomed with screen shown in Figure 9 which displays two available options which are sign in and register button for first time users. If the user chooses to login into the app, they will be redirected to the login interface shown in Figure 10. First time users are required to create a new account by filling the Waqif Registration Form in the Figure 11. After successfully registered a new account, users will be redirected back to the login page. Figure 12 shows an example of waqf asset registration form. Users can upload proof of their ownership of the current asset or properties before submitting the application. Figure 13 shows an example of proof of ownership uploaded by a user which is currently in processing status on the left tab. If the asset or property has been approved, the status of the application should be displayed on the right tab. 


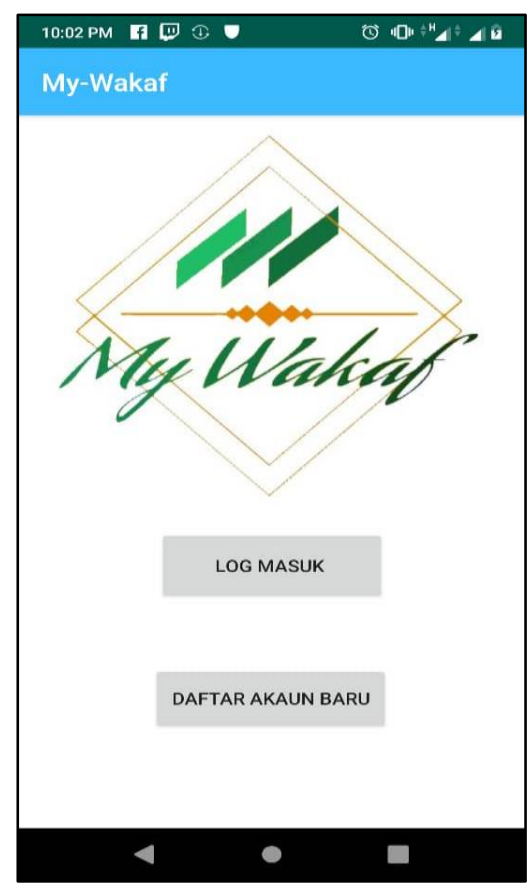

Figure 9: Main Menu Interface

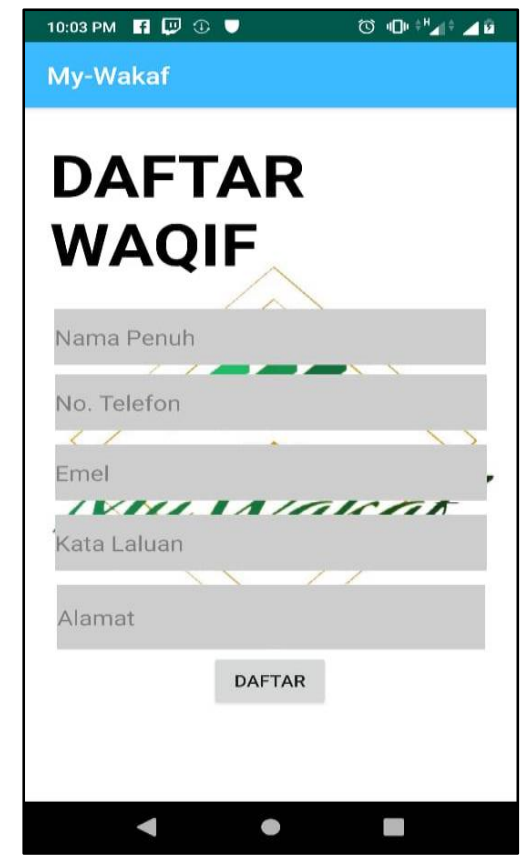

Figure 11: Waqif Registration Interface

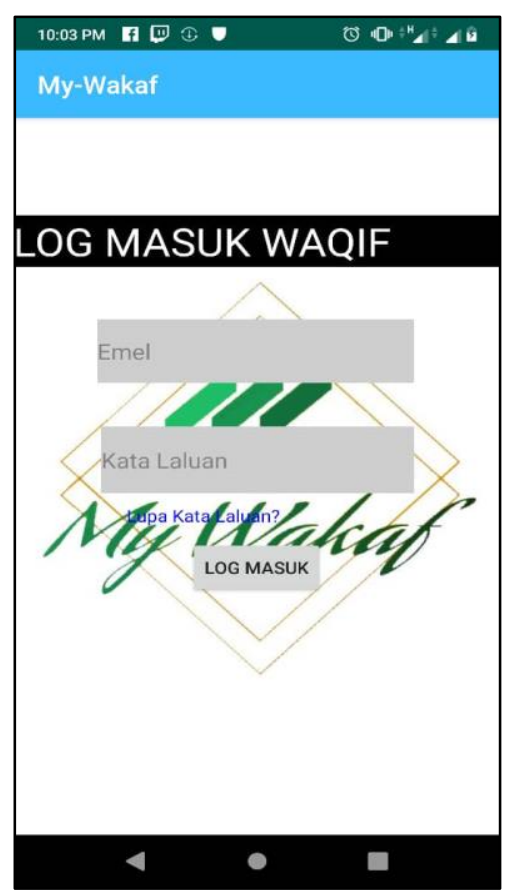

Figure 10: Waqif Login Interface

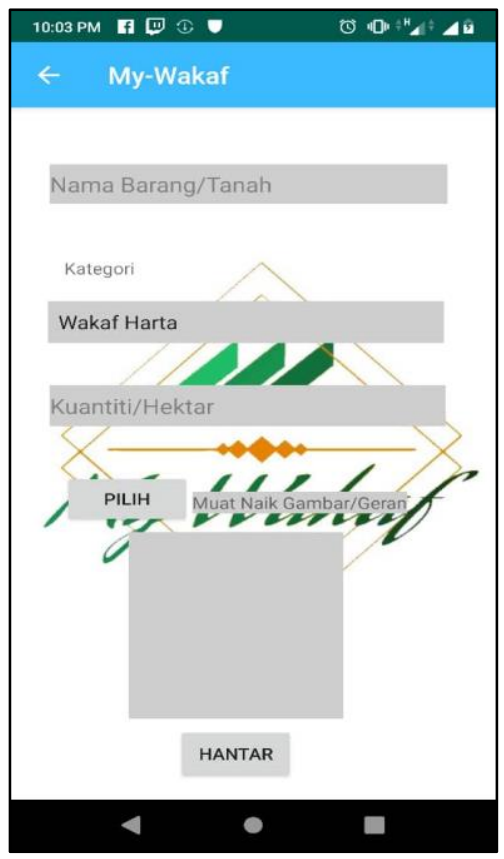

Figure 12: Item Registration Interface 


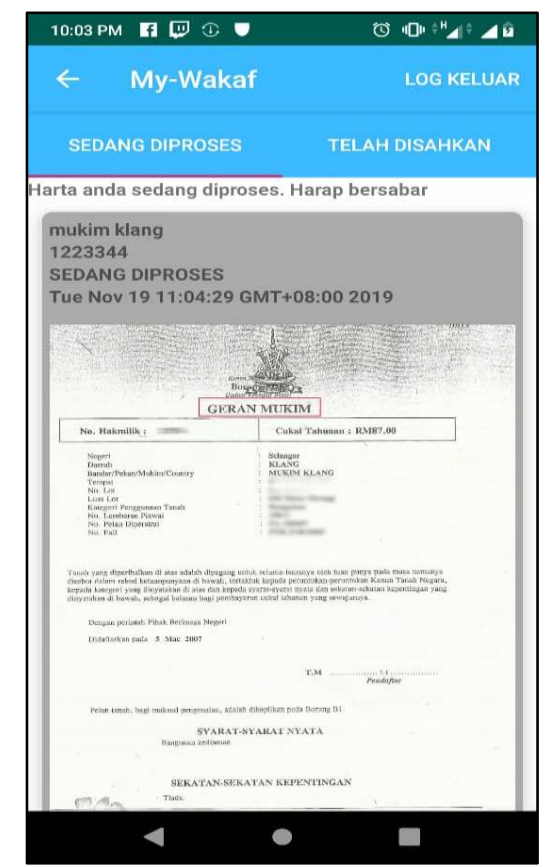

Figure 13: Sedang Diproses Fragment

\section{Web Application Interface}

As for the nazir/staff/administrator, the credentials in the staff login form can only accepted if the user level is staff to prevent unauthorized access. Based on Figure 14, the staff needs to fill in details such as email and password to login into the system.

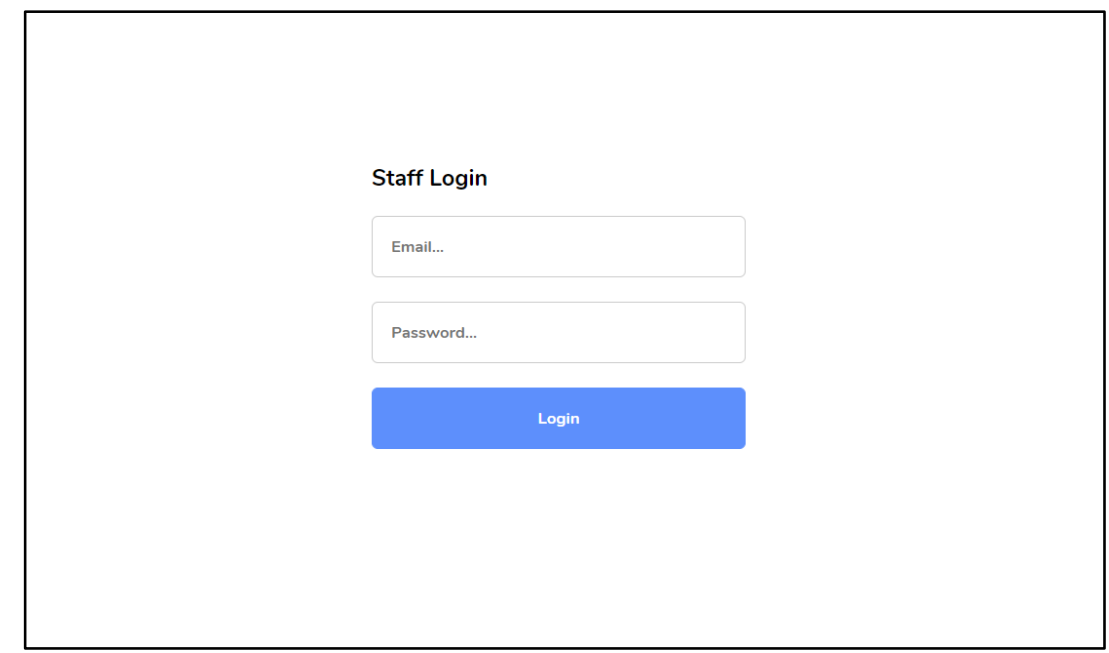

Figure 14: Nazir/Staff/Administrator Login Page 
After successfully login, staff users will be redirected to a welcome page as shown in Figure 15 where two options which are logout or to view reports on all waqf application (mawquf) in the database. Figure 16 shows all the registered waqf asset or mawquf which the staff can perform actions such as to validate or approve the applications or delete the application the registered item based on the regulations of waqf. If the application is validated, the date is also recorded as part of the validation process. Waqif can simply log in again into their mobile application to see their application status.

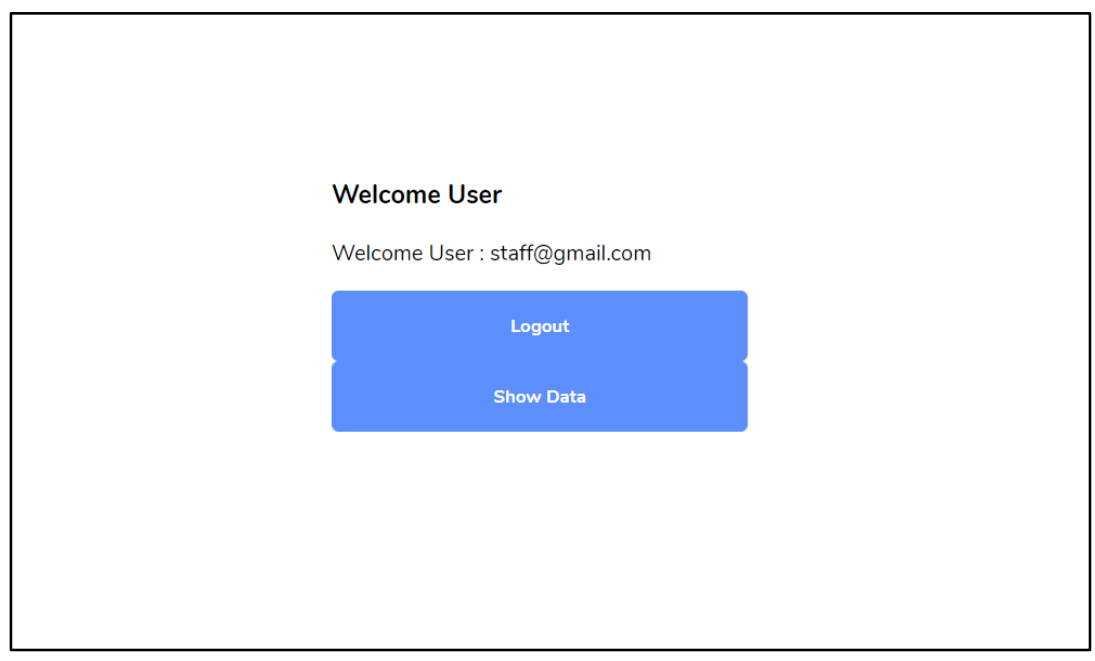

Figure 15: Staff Welcome Page

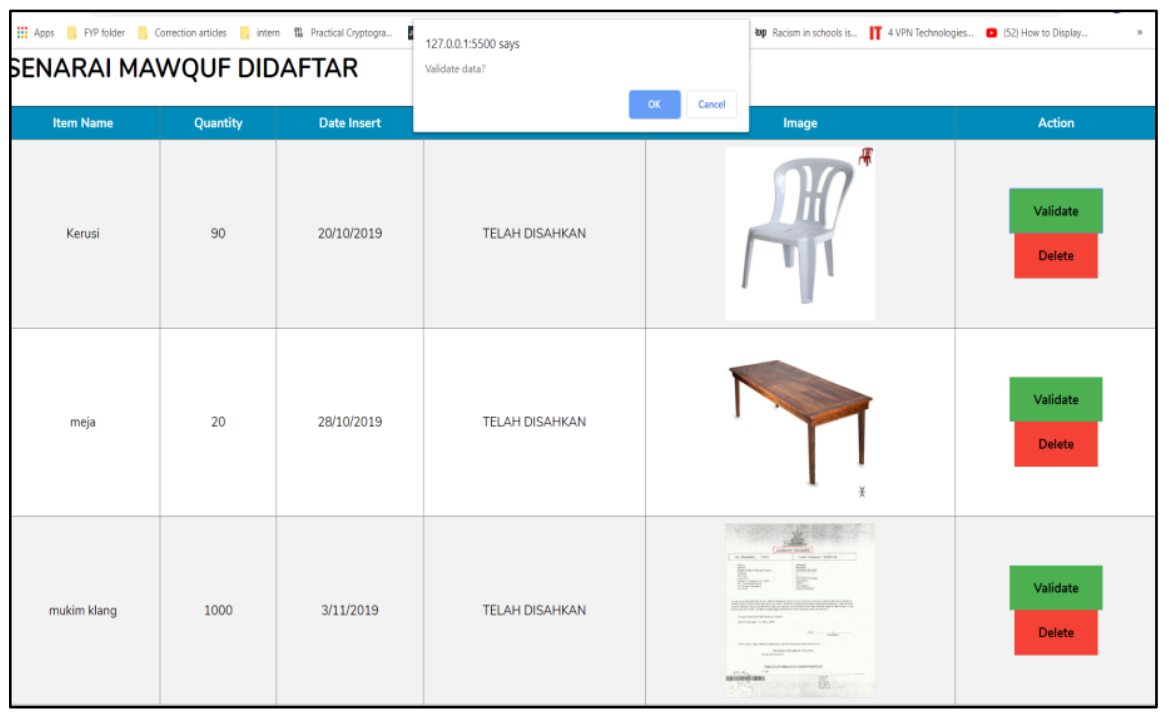

Figure 16: List of Waqf Assets/Property (Mawquf) application 


\section{FINDINGS AND DISCUSSIONS}

This section discussed the findings of this study. Before performing the User Acceptance Test, functionality testing is performed first to ensure all key components or modules of the mobile app and web application to work properly.

User acceptance testing is the last phase of the system testing process. During the testing process, the respondents test the mobile application and the web application to make sure it can handle required tasks in real-world scenarios, according to the specifications. In addition of that, user acceptance testing also is to determine whether the system can be accepted or not.

\section{Descriptive Analysis}

Based on the mean results shown in Table 1 below, it can be concluded that the application is accepted by respondents to used. Based on the means calculation of summary of user acceptance, showing all the respondent says that the application was satisfied the user expectation.

Table 1: Mean Calculation of User Acceptance Test

\begin{tabular}{|c|c|c|c|c|}
\hline Criteria & Question & Min & $\operatorname{Max}$ & Mean \\
\hline $\begin{array}{l}\text { Reaction to the } \\
\text { application }\end{array}$ & $\begin{array}{l}\text { I'm able to complete all the tasks in this } \\
\text { application. }\end{array}$ & 4 & 5 & 4.85 \\
\hline $\begin{array}{l}\text { Reaction to the } \\
\text { application }\end{array}$ & This application is easy to use. & 4 & 5 & 4.70 \\
\hline $\begin{array}{l}\text { Reaction to the } \\
\text { application }\end{array}$ & This application is really useful & 4 & 5 & 4.60 \\
\hline Interface Design & The user interface design is interesting. & 3 & 4 & 4.10 \\
\hline Interface Design & The color used is attractive & 3 & 4 & 4.15 \\
\hline Interface Design & The text is clear and readable. & 3 & 5 & 4.6 \\
\hline Navigation & $\begin{array}{l}\text { It is easy to move from one activity to another } \\
\text { activity. }\end{array}$ & 4 & 5 & 4.8 \\
\hline Navigation & The button provided is easy to interact. & 4 & 5 & 4.8 \\
\hline Navigation & The instruction given is clear. & 3 & 5 & 4.6 \\
\hline Content & The content provided is clear and well arrange. & 5 & 4 & 4.45 \\
\hline Content & The information provided is easy to understand. & 4 & 5 & 4.65 \\
\hline Content & $\begin{array}{l}\text { The application has all the functions according } \\
\text { to user expectation. }\end{array}$ & 4 & 5 & 4.9 \\
\hline
\end{tabular}

\section{Frequency Analysis}

Table 2 and Figure 17 below shows the percentage of each criterion from all respondents. Reaction to the application is mostly positive due to good first impression on the app and promising since the application can achieve its main objective by helping users to apply for waqf application. Navigation criteria also shown good percentage, since respondents can navigate within the application with less learning curve needed. Content is also on point however some respondents suggested more improvement to the application, especially on the user interface design. Overall, majority of respondents are satisfied with their whole experience testing this mobile application. 
Table 2: Frequency Analysis of User Acceptance Test

\begin{tabular}{|c|c|c|c|c|c|}
\hline $\begin{array}{l}\text { Criteria / } \\
\text { Scale }\end{array}$ & $\begin{array}{l}\text { Strongly } \\
\text { Disagree }\end{array}$ & Disagree & Neutral & Agree & $\begin{array}{c}\text { Strongly } \\
\text { Agree }\end{array}$ \\
\hline $\begin{array}{l}\text { Reaction to } \\
\text { application }\end{array}$ & 0 & 0 & 0 & 28.3 & 71.6 \\
\hline $\begin{array}{l}\text { Interface } \\
\text { design }\end{array}$ & 0 & 0 & 13.3 & 45 & 41.6 \\
\hline Navigation & 0 & 0 & 1.6 & 23.3 & 75 \\
\hline Content & 0 & 0 & 0 & 33.3 & 66.6 \\
\hline
\end{tabular}

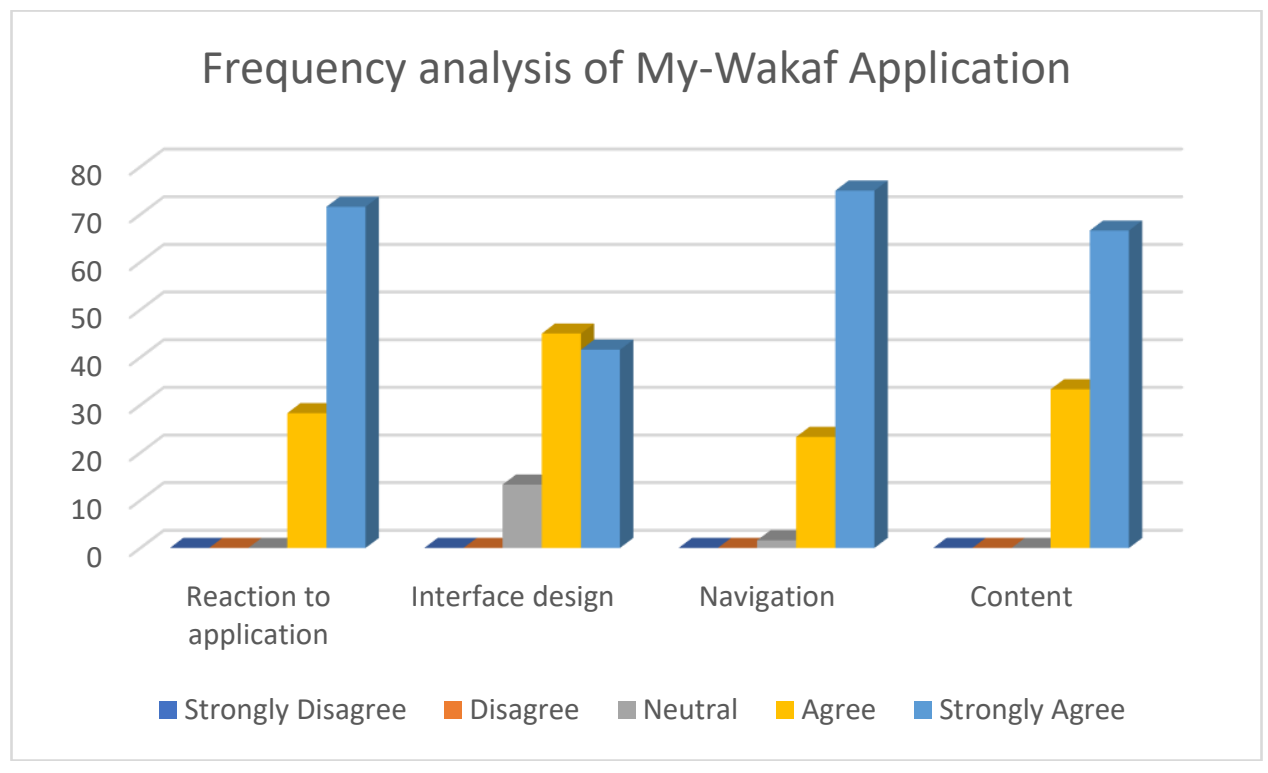

Figure 17: Summary of frequency analysis

\section{CONCLUSION AND RECOMMENDATIONS}

As a conclusion, the proposed My-Wakaf application can assist users to apply for waqf easily rather than using conventional manual method. Not only it can benefit the State Islamic Religious Council to streamline their information management instead of using traditional method, but it can also help to spread awareness on the knowledge of waqf to the whole Muslim community. For recommendation or future work, a better user interface is needed to improve the user experience while using this application as suggested by few respondents. Database should also be expanded to cater more information about waqf assets and properties. In addition, the lack of notification feature is one of the limitations of this app. Such function will be added in the future to further help users to be updated instantly regarding their application status instead of frequently logging in into the app from time to time. 


\section{ACKNOWLEDGMENTS}

The authors wish to thank Universiti Teknologi MARA, Perlis Branch, Arau Campus for their support in completing this research.

\section{REFERENCES}

Abas, F. N., \& Raji, F. (2018). Factors Contributing to Inefficient Management and Maintenance of Waqf Properties: A Literature Review. UMRAN - International Journal of Islamic and Civilizational Studies, 5(3), 53-67. https://doi.org/10.11113/umran2018.5n3.233

Abd Jalil, M. I. (2020). Issues and Challenges of Waqf Practice in Malaysia: A Review. Labuan E-Journal of Muamalat And Society (LJMS), 14(December), 80-86.

Hasan, Z. A., Othman, A., Ibrahim, K., Md Shah, M. A. M., \& Noor, A. H. M. (2015). Management of Waqf Assets in Malaysia. International Journal of Nusantara Islam, 3(1), 59-68. https://doi.org/10.15575/ijni.v3i1.412

Hassan, A., \& Shahid, M. A. (2010). Management and Development of the Awqaf Assets. Seventh International Conference - The Tawhidi Epistemology: Zakat and Waqf Economy, 309-328. https://doi.org/10.1109/incos.2010.100

Komalasari, R. (2020). The Waqf Cemetery Information System. IOP Conference Series: Materials Science and Engineering, 879(1). https://doi.org/10.1088/1757-899X/879/1/012035

Mat Rani, M. A., \& Abdul Aziz, A. (2010). Waqf management and administration in Malaysia: its implementation from the perspective of Islamic law. Malaysian Accounting Review, Special Issue, 9(2), 1-7. http://arionline.uitm.edu.my/ojs/index.php/MAR/article/view/237

Mohd Noor, A. H., Mohd Ali, N. A., Abdullah, A., \& Mohd Tahir, H. H. (2014). The Waqf Governance Framework in Malaysia. International Conference On Development Of Social Enterprise And Social Business For Eradication Of Extreme Poverty And Street Begging, IIUCIC7-2014/ IC7-160. https://www.researchgate.net/profile/Nor_Mohd_Ali2/publication/283318966_The_Waqf_Governa nce_Framework_in_Malaysia/links/5632f6fc08ae242468da078d.pdf

Mukti, T. (2021). Implementation of Digital Based Wakaf in Campus Environment as Education and Administration Since Early (Innovation in Management of Zakat and Waqf in the Student Environment). In Islamic Sosial Finance and Its Role for Achieving Sustainable Development Goals: Islamic Economics Winter Course (p. 175). PT Penerbit IPB Press, 2021. https://books.google.com.my/books?hl=en\&lr=\&id=LAYlEAAAQBAJ\&oi=fnd\&pg=PA175\&ots=1 pMymObWdJ\&sig=5N5enwFSuPD1p7VAL4C-MT2oGyU\&redir_esc=y\#v=onepage\&q\&f=false 